GEOGRAFICKÝ ČASOPIS / GEOGRAPHICAL JOURNAL 71 (2019) 3, 283-293

DOI: https://doi.org/10.31577/geogrcas.2019.71.3.15

\title{
PUBLIKOVANIE GEODÁT VO FORME VEKTOROVÝCH DLAŽDÍC A POROVNANIE VÝKONU S RASTROVÝMI DLAŽDICAMI
}

\author{
Jozef Fábry, Richard Feciskanin* \\ * Univerzita Komenského v Bratislave, Prírodovedecká fakulta, Katedra kartografie, geoinformatiky a dial'kového \\ prieskumu Zeme, Ilkovičova6, 84215 Bratislava, fabry24@uniba.sk, richard.feciskanin@uniba.sk
}

\begin{abstract}
Publishing geodata in the form of vector tiles and comparing performance with raster tiles

In recent years, the publishing of geodata on the Internet has been a clear move towards using vector tiles. The difficulty of tasks for rendering vector data, where cartographic representation is provided from the side of the client, is greater than in raster data. Much attention is paid to the preparation of vector tiles and their optimization. Little interest is given to the negative effect of using vector tiles, such as higher load and time to render content on the web client. In this article we deal with vector tile issues and their use in web cartography for transfer data from server to client. Our main goal was to create a test application that quantitatively evaluates the use of vector tiles compared to traditional raster tiles. We briefly introduce vector tiles, available standards and formats and the technology used to work with them. The last part of this article deals with the detailed description of data preparation and the creation of the test application itself and describes the achieved results from the measurements carried out.
\end{abstract}

Key words: vector tile, rendering, web map, web map tile service

\section{ÚVOD}

Vývoj webovej kartografie sa za posledné roky posunul vpred najmä v súvislosti s informačnými technológiami a technológiami naviazanými na rozvoj internetu. Rozvoj týchto technológií so sebou prináša vel'ké množstvo údajov, najmä priestorových, ktoré je možné vizualizovat'. Prezentovat' dáta ako jednoduché statické mapy nie je postačujúce. S rastúcim objemom dát je potrebné zlepšovat' výkon mapových aplikácií, optimalizovat' prenos dát a urýchl'ovat' a vylepšovat' vykresl'ovanie. Spojenie výhod vektorových dát a hierarchického delenia podl'a dlaždicovej schémy používanej tradične pri rastrových dátach je odpoved'ou na tieto požiadavky. Vektorové dáta umožňujú pokročilé vizualizačné metódy a interaktívne mapy, ktoré sa užívatel'ovi prispôsobujú v závislosti od jeho potrieb a požiadaviek. Dáta získané zo servera vo forme vektorových dlaždíc zachovávajú výhody vektora (štýlovanie na základe atribútov, interaktívna zmena kartografickej reprezentácie, atribútové dopytovanie a pod.). Nie je nutné využívat' spôsob prezentácie dát, ktorý je preddefinovaný na serveri, alebo posielat' na server dopyt s vlastným vytvoreným štýlom, ako to je pri WMS (Web Map Service), resp. WMTS (Web Map Tile Service). Ciel'om príspevku je kvantitatívne vyjadrit' zmeny, ktoré prináša používanie vektorových dlaždíc v porovnaní s rastrovými dlaždicami. Zamerali sme sa na overenie rozdielov času pri vykresl'ovaní i získavaní dát a ich vel'kosti. Načrtneme stručnú históriu vývoja vektorových dlaždíc, postup vytvárania a možnost' generovania dlaždíc. V metodickej časti uvedieme spôsob spracovania dát, postup meraných veličín, proces vykreslovania. Na záver predstavíme zhodnotenie dosiahnutých výsledkov porovnania výkonnosti rastrových a vektorových dlaždíc. 
Problematike vykresl'ovania symboliky dát s použitím vektorových dlaždíc sa nevenuje mnoho pozornosti. Môžeme spomenút' napríklad prácu autorov Li et al. (2017), ktorí sa zaoberajú problematikou vykresl'ovania symboliky pre bodové, líniové a polygónové vrstvy na hraniciach medzi dlaždicami a nepresahovaním symboliky z jednej dlaždice do susednej dlaždice. Jednou z d'alších prác venovanou výkonu vektorových dlaždíc bola diplomová práca Adamca (2016), ktorý sa zameral na optimalizáciu prenosu dát pomocou RUIAN-u (Registr územní identifikace, adres a nemovitostí) s využitím technológie vektorových dlaždíc. $Z$ dosiahnutých výsledkov vyplýva, že formát údajov TopoJSON sa javí ako výhodnejší formát na zmenšenie vel'kosti dát v porovnaní s formátom GeoJSON. Využitie vektorových dlaždíc môže byt' široké, Li et al. (2018) ich vo svojej práci využili na vytvorenie novej technológie GeoTile, ktorá slúži na spoločné využívanie a výmenu geopriestorových dát kooperatívnym spôsobom. GeoTile používa formát GeoJSON na rozdelenie vel'koplošných údajov na malé jednotky. V práci Janečku a Bobíkovej (2018) sa vektorové dlaždice využívajú na optimalizáciu načítavania 3D dát z priestorovej databázy.

\section{VEKTOROVÉ DLAŽDICE}

Pojem vektorové dlaždice definoval už v 60. rokoch 20. storočia Kanadský geografický informačný systém - CGIS (Canada Geographic Information System) ako schému ukladania vektorových dát tak, aby ich počítač dokázal efektívnejšie spracovat'. V 70. rokoch 20. storočia vyvinula firma Autometric analytický mapovací systém mokradí WAMS (Wetlands Analytical Mapping System), kde sa v úložisku dát využivali vektorové dlaždice (Pywell a Niedzwiadek 1980). V 80. rokoch 20. storočia vydala firma Autometric komerčný GIS, ktorý poskytoval zdokonalený prístup a formu ukladania vektorových dlaždíc. Tento GIS bol pomenovaný DeltaMap a neskôr sa premenoval na GenaMap. Rozdiel medzi softvérmi DeltaMap a WAMS bol v tom, že užívatel' dokázal v DeltaMap definovat' l'ubovol'nú vel'kost' dlaždice a referenčný systém, zatial' čo WAMS mal implementovanú pevnú šírku dlaždice (Reed 2017). Vektorové dlaždice sa v súčasnej podobe použivajú od roku 2010 (Google Inc. 2010). Nemajú vyvinutý vlastný štandard, ale je možné využívat' štandard WMTS alebo WFS na tvorbu vektorových dlaždíc (OGC 2018a). Konzorcium OGC koordinovalo niekol'ko testovaní a plánujú technológiu vektorových dlaždíc zahrnút' do špecifikácie WMTS, WFS 3.0, GeoPackage 1.2. Výsledky dosiahnuté testovaním ukázali, že po určitých rozsiahlejších úpravách by bol takýto krok možný (OGC 2018b). Spoločnost' Mapbox prispela k rozšíreniu používania vektorových dlaždíc vytvorením otvorenej špecifikácie označovanej Mapbox Vector Tile - MVT (Mapbox 2017); pre zjednodušenie d'alej označujeme vektorové dlaždice podl'a tejto špecifikácie ako formát MVT.

Pri prenášaní vektorových dát $\mathrm{z}$ rozsiahlejších dátových súborov je problémom ich vel'kost'. Pri menších mierkach je zároveň pravdepodobný výskyt väčšieho počtu objektov. Tieto objekty obsahujú okrem geometrie aj atribúty. To všetko spôsobuje kritické problémy pri prenose vektorových dát, na rozdiel od rastrových obrazov z nich vygenerovaných. Po úspechu prenosu dát vo forme rastrových obrazových dlaždíc sa začalo uvažovat' o podobnej technológii aj pre vektorové dáta. Riešením problému s vel'kost'ou je využitie vektorových dlaždíc (Antoniou et al. 2009). Delenie na časti rieši problém s objemnými vektorovými prvkami, pričom hierarchický charakter dlaždíc pomáha s celkovým množstvom dát. 
Jedna dlaždica je zvyčajne štvorcový výrez priestorových dát, ktorý obsahuje geometrickú a atribútovú informáciu. Samotná geometria vektorového prvku je rozdelená podl'a BBOX-u (hranice) dlaždice. Táto skutočnost' zapríčiňuje, že ku klientovi príde iba určitý počet objektov, ktorý sa nachádza na dlaždici, a nadbytočné dáta mimo územia neprídu. Takto rozdelené dáta, majú čas prenosu ku klientovi menší. Vel'kú úlohu pri prenose dát zohráva ich generalizácia, ktorá je výraznejšia pri nižších hodnotách priblíženia. Následne, pred samotným zobrazením, dochádza na klientovej strane $\mathrm{k}$ rekonštrukcii dát do pôvodnej podoby tým, že sa dlaždice spoja do kompletnej geometrie (Mapbox 2016).

Obrázok 1 demonštruje postup generovania dlaždíc. Ako vstup slúžia vektorové dáta, ktoré sa rozdelia do predurčenej mriežky na každej úrovni priblíženia. Najčastejšie používaná mriežka vychádza zo zobrazenia WGS 84 / Pseudo-Mercator (EPSG:3857). Následne po rozdelení dát do mriežky, sa môže jeden objekt nachádzat' na viacerých dlaždiciach a na jednej dlaždici viacero objektov (Gaffuri 2012). Pre vektorové dlaždice formátu MVT je odporúčaný súradnicový systém EPSG:3857. Celý svet je zobrazený na jednej dlaždici (vel'kost' $512 \times 512$ px), čo je úroveň priblíženia 0, približná mierka je 1:250 000000 a rozlíšenie je $78 \mathrm{~km} / \mathrm{px}$. V každej d’alšej úrovni priblíženia je rozlíšenie dvojnásobné a počet dlaždíc štvornásobne vzrastie. V celom rozsahu sú 4 dlaždice v úrovni priblíženia $1, \mathrm{v}$ úrovni 2 je dlaždíc 16, v úrovní 3 je dlaždíc 64, atd'. (Openstreetmap Wiki Contributors 2019).

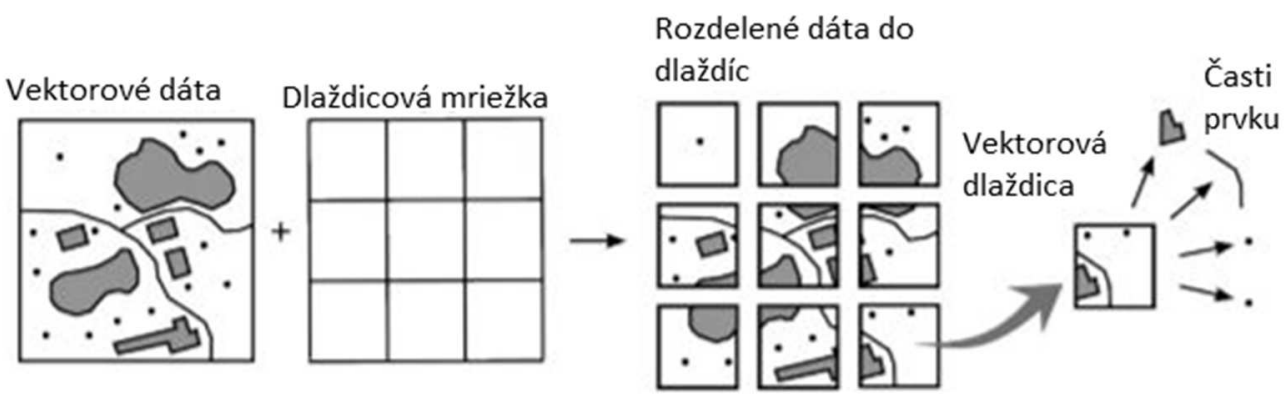

Obr. 1. Princíp tvorby vektorových dlaždíc (podl’a Gaffuri 2012)

V nasledujúcej časti sa budeme zaoberat' formátom MVT, ktorý je vyvinutý tak, aby požadované údaje boli súvislo $\mathrm{v}$ pamäti a aby vrstvy mohli byt bez úpravy údajov pripojené $\mathrm{k}$ dlaždici. Každá dlaždica by mala obsahovat' aspoň jednu vrstvu, vrstva aspoň jeden prvok a prvok musí obsahovat' pole geometrie. Prvky dlaždice obsahujú id, atribúty a geometriu, ktorá môže byt' bod, línia alebo polygón a geometrie sa ukladajú ako pole čísel $x$ a $y$. Vrstva musí obsahovat položku s menom a na jednej dlaždici nesmú byt' dve alebo viacero vrstiev s identickou hodnotou tejto položky. Začiatok dlaždice je v l'avom hornom rohu a koniec dlaždice je na dolnom okraji alebo v pravom dolnom rohu (Mapbox 2017).

Dáta uložené v dlaždici môžu byt' rôznych dátových typov. Podporované sú ret’azce typu unicode, booleovské hodnoty a rôzne typy s celočíselnými alebo desatinnými číslami (Thompson 2016). Vrstva musí zahŕnat’ rozsah, ktorý popisuje šírku a výšku dlaždice v celočíselných (integer) súradniciach. Geometrie prvkov sú definované v súradnicovom systéme obrazovky, z dôvodu minimálnej réžie klienta 
na prípravu vykresl'ovania geometrie za pomoci rozhrania WebGL a Canvas, ktorej kód sa spúšt'a na grafickej karte klienta. L'avý horný roh je počiatkom súradnicového systému. Kladná os $X$ smeruje doprava a kladná os $Y$ smeruje nadol. Súradnice $v$ rámci geometrie musia byt' celočíselné hodnoty (integer). Geometria je kódovaná ako postupnost' 32-bitových celočíselných hodnôt v poli geometrie prvku. Samotná geometria prvkov v dlaždici môže presahovat' hranice definované rozsahom. Presahujúce geometrie slúžia ako vyrovnávacia pamät' na vykresl'ovanie prekrývajúcich sa susedných dlaždíc. Rozsah dlaždice je 4096 a súradnicové jednotky vo vnútri dlaždice sa vzt’ahujú na 1/4 096 štvorcových rozmerov. Súradnica 0 je na hornom alebo l'avom okraji dlaždice a súradnica 4096 je na spodnom alebo pravom okraji. Súradnice od 1 do 4095 sú úplne v rozsahu dlaždice. Súradnice menšie ako 0 alebo väčšie ako 4096 sú úplne mimo rozsahu dlaždice (Mapbox 2017). Konverzia z geografických súradníc na súradnice vektorových dlaždíc je dôležitým krokom, kde sú súradnice zaokrúhlené na celé čísla. Zjednodušovanie údajov sa vykonáva v minimálnej nevyhnutnej miere (Mapbox 2016). Na prenos pripravených a zakódovaných dát vektorových dlaždíc sa využíva formát pbf - Google Protocol buffer, ktorý kóduje atribúty ako páry hodnôt.

V súčasnosti je dostupné vel'ké množstvo nástrojov a aplikácií, ktoré sa zaoberajú vektorovými dlaždicami - či už ide o serverové alebo klientske riešenia. Mnohé sú vol’ne dostupné s otvorenými zdrojovými kódmi, spomenieme niektoré z nich. Pokročilé možnosti generovat' vektorové dlaždice vo formáte MVT ponúka Tippecanoe. Generuje dlaždice zo vstupných dát formátov GeoJSON, Geobuf alebo CSV (Fischer 2017). Dalej je možnost' generovat' vektorové dlaždice vo vol'ne dostupnom softvéri GeoServer. Generuje dlaždice v kódovaní pbf a zakódované dáta odosiela klientovi. Výstupnými formátmi z GeoServera môžu byt' GeoJSON, TopoJSON, MVT (Henneberger 2015). Dalším zo serverových riešení využitia vektorových dlaždíc je server TileStache. Poskytuje dáta vo forme mapových dlaždíc, ktoré môžu byt' rastrové aj vektorové. Vektorové výstupy môžu byt' rovnako vo formáte GeoJSON, TopoJSON, MVT (označený ako pbf - Migurski 2019). Klientskych riešení v oblasti danej problematiky je taktiež niekol'ko. Spomenieme napríklad javascriptové knižnice MapboxGL (od autorov špecifikácie MVT), OpenLayers, Leaflet. OpenLayers spracováva formáty GeoJSON, TopoJSON a MVT. Leaflet spracováva formáty GeoJSON a MVT a MapboxGL nimi vyvinutý formát MVT.

\section{METODIKA}

$\mathrm{V}$ našom experimente sme primárne sledovali priebeh vykresl'ovania dát a čas prenosu zo servera ku klientovi vo vektorových a obrazových dlaždiciach s využitím mapovej služby WMTS. Doplnkovým sledovaným javom bola vel'kost' dát v dlaždiciach. Experiment sme realizovali v otvorených softvéroch QGIS 3.6, mapový server GeoServer 2.13.2, klientsku webovú aplikáciu sme tvorili s využitím OpenLayers 5.3.0 a použili sme vol'ne dostupné testovacie dáta z Openstreetmap. Dôvodov pre výber konkrétnych platforiem bolo niekol'ko, v prvom rade rozsiahly prístup k úprave dát (QGIS), využitel'nost' mapových služieb OGC štandardov na strane servera (GeoServer), publikovanie formátu vektorových dlaždíc podl'a špecifikácie MVT (GeoServer) a v neposlednom rade udalosti knižnice, ktoré nám pomohli získat' potrebné údaje o prenose dát vrstiev zo strany servera a o spôsobe vykresl'ovania vrstiev na strane klienta (OpenLayers). Vol'ba nám umožnila použit' rovnaké nástroje pre vektorové a rastrové dlaždice a tým priame porovnanie oboch typov dlaždíc. Zámerne sme nevyužili súbor nástrojov od spoločnosti Mapbox, kde 
je optimalizácia spracovania a použitia dát na vysokej úrovni a nemohli by sme tak predstavit' potenciálne problémy pri používaní vektorových dlaždíc.

Vstupné dáta pre experiment sme získali vo formáte shapefile a upravili sme ich v softvéri QGIS. Dáta z testovacieho územia Bratislavského a Trnavského samosprávneho kraja obsahovali bodové, líniové a polygónové vrstvy. Bodové vrstvy zahŕňali mestá a obce pre zobrazovanie popisov. Líniové obsahovali cesty a rieky, polygónové budovy, využitie krajiny, polygónovú reprezentáciu vodstva (rieky a vodné plochy) a oblast' testovacieho územia. Úprava dát zahŕňala orezanie vrstiev podl'a hranice testovacieho územia. Dáta boli publikované zo servera GeoServer, kde bolo implementované rozšírenie vektorových dlaždíc. Štýly vrstiev použité v mapovej aplikácii boli vyrobené v prostredí Maputnik vo formáte JSON, ktorý sa aplikoval pre oba typy dlaždíc. Porovnávali sme dva rôzne formáty dát získavaných zo servera. Vektorové dlaždice formátu MVT boli získané v kódovaní .pbf a rastrové dlaždice boli získané vo formáte .png8, ktorý obsahuje indexované farby s 8-bitovými vzorkami s podporou priehl'adnosti (Roelofs 2006).

Testovacia aplikácia beží na vlastnom serveri, kde je implementovaný aj mapový server so vzorovými dátami. Merania časov (čas vykreslenia, čas prenosu zo servera) prebiehali na počítači s rýchlost'ou st'ahovania $\mathrm{z}$ internetu $90 \mathrm{Mb} / \mathrm{s}$ a s rýchlost'ou nahrávania na internet $84 \mathrm{Mb} / \mathrm{s}$, ping na server $<1 \mathrm{~ms}$ a priemerný čas získania prvého bitu bol $11,3 \mathrm{~ms}$. Na počítači prebehlo pät' meraní pre vektorové dlaždice a pre rastrové dlaždice. Meranie pozostávalo z 12 zmien pohl'adu, ktoré simulujú činnost' používatel'a s mapou. Výsledné hodnoty získané pri konkrétnom kroku zmeny pohl'adu sa spriemerovali. Zaznamenávali sme počet dlaždíc, čas jednotlivých behov vykreslenia častí vrstiev, ktoré prišli ku klientovi (minimum, maximum a priemer). Vrstvy neboli posielané naraz vcelku, ale postupne po určitých počtoch dlaždíc, $z$ dôvodu obmedzenia paralelných dopytov na server cez HTT$\mathrm{P} / 1.1$. Tento jav sa odzrkadlil na skutočnosti, že kým sa korektne vykreslili všetky prvky a dlaždice, prebehlo niekol'ko cyklov vykresl'ovania, v ktorých sa vykresl'ovali novoprijaté dlaždice a prekresl'ovali dlaždice, ktoré sa vykresl'ovali v predošlých cykloch (obr. 2). Určili sme čas od začiatku prvého po ukončenie posledného behu vykreslenia jedného pohl'adu v mapovom poli. Dalej sme zaznamenávali čas prenosu dlaždice zo serveru ku klientovi (minimum, maximum a celkový čas) a vel'kost' dlaždíc, ktorá bola automaticky zaznamenávaná vývojárskou konzolou webového prehliadača. Dlaždice boli predgenerované a uchovávané na strane servera. Na meranie vykresl'ovania dlaždíc sme použili udalosti knižnice OpenLayers - precompose a postcompose. Na meranie času, za ktorý klient získal dlaždicu zo servera, sme využili udalosti knižnice tileloadstart, tileloadend a tileloaderror, pomocou ktorých sme zaznamenávali začiatok a koniec prenosu dlaždíc. Následne sme potom určili celkový čas prenášaných dlaždíc pri jednotlivých hodnotách priblíženia a pohybov. Časy získané pomocou skriptu sme zaznamenávali vo vývojárskej konzole prehliadača. Vel'kost' dlaždice sme získali z vývojárskej konzoly zo záložky network, kde sa vel'kost' dlaždíc zaznamenávala automaticky.

Iniciálna hodnota priblíženia pri štarte aplikácie je 8,5. Postupne je mapa približovaná až na hodnotu 16 so zachovaným stredom územia v poradí 8,5-10-11$12-13-14-15-16$. V hodnote priblíženia 16 je mapa posunutá 4-krát v poradí $0.10^{\circ}$ severne $-0.05^{\circ}$ východne $-0.10^{\circ}$ južne $-0.05^{\circ}$ východne. Po poslednom posune mapy sa mapa oddiali na hodnotu priblíženia 12. Každý krok posunu alebo zmeny priblíženia sa vykonáva bez animácie po 12 sekundách z dôvodu kompletného načítania a vykreslenia vrstiev. 


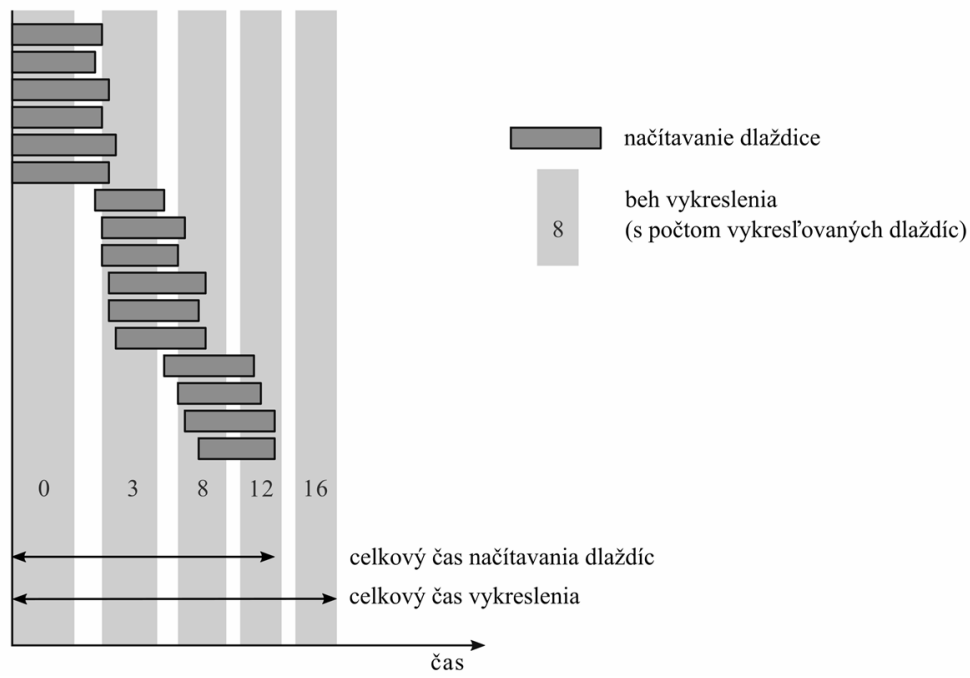

Obr. 2. Schéma postupnosti vykresl’ovania dlaždíc v jednom pohl’ade

V tabul'ke 1 vidíme prehl'ad vykresl'ovaných vrstiev na základe hodnôt priblíženia. Od úrovne 14 mal klient $\mathrm{k}$ dispozícii všetky typy dát, ktoré sme v našej aplikácii publikovali. V úrovni 14 sú však generalizované, preto boli načítavané až po úroveň 16.

Tab. 1. Vykreslené vrstvy pri jednotlivých hodnotách priblíženia

\begin{tabular}{cl}
\hline Hodnota priblíženia & Vykreslené vrstvy \\
\hline 8,5 & $\begin{array}{l}\text { využitie krajiny } \\
\text { testovacie územie } \\
\text { polygónová reprezentácia vodstva } \\
\text { dial'nice, rýchlostné cesty, cesty I. triedy } \\
\text { okresné mestá }\end{array}$ \\
\hline $\begin{array}{l}\text { rieky } \\
\text { cesty II. triedy } \\
\text { cesty III. triedy } \\
\text { mestá }\end{array}$ \\
\hline 10 & obce a mestské časti \\
& $\begin{array}{l}\text { uličná siet’ v obciach } \\
\text { ostatné cesty (nespevnené, lesné, ...) } \\
\text { štvrte mestských častí }\end{array}$ \\
\hline 11,13 & budovy \\
& zvyšné, predtým nevykreslené dáta \\
\hline $14+$ &
\end{tabular}




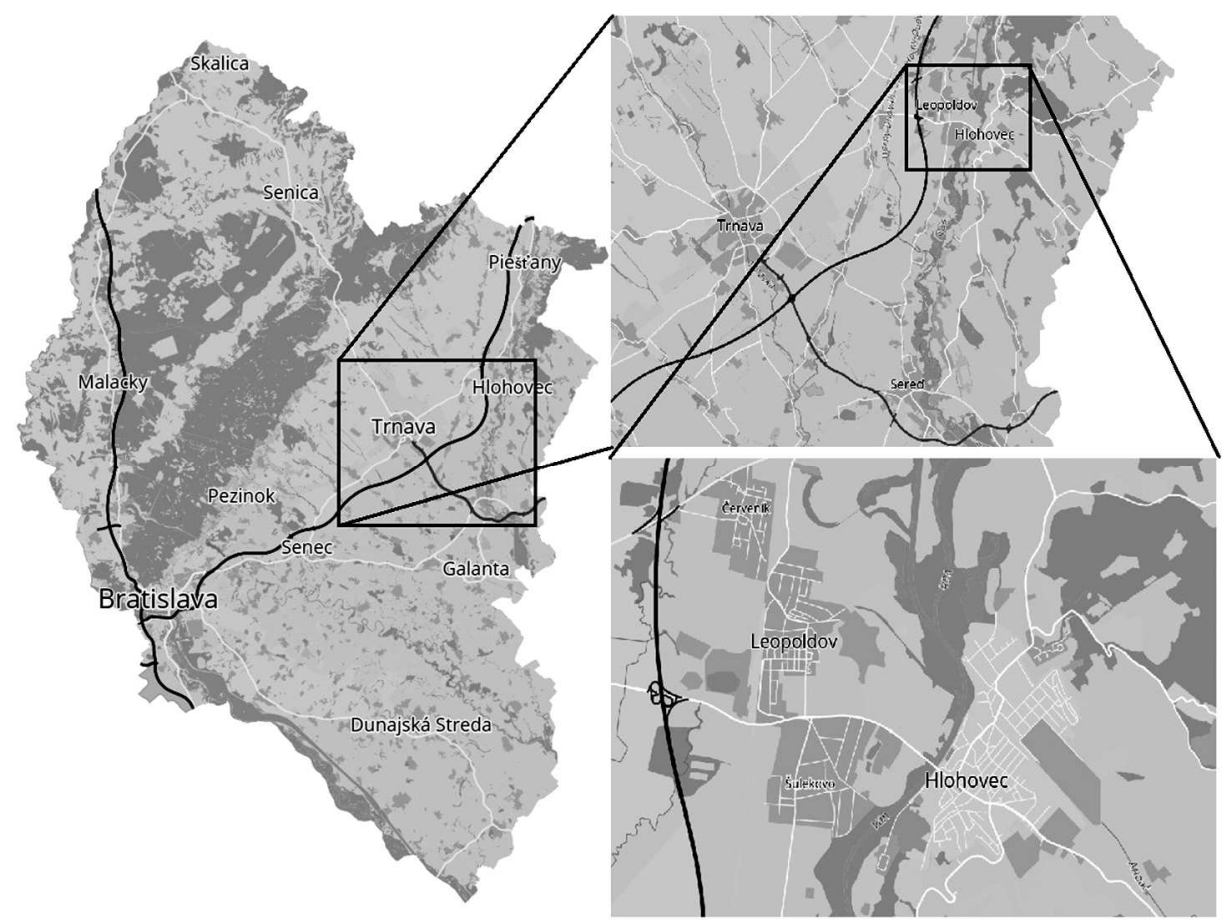

Obr. 3. Ukážka hodnôt priblíženia na území západného Slovenska vlavo priblíženie $=8,5$; vpravo hore priblíženie $=10$; vpravo dole priblíženie $=12$

\section{VÝSLEDKY A DISKUSIA}

Základné výsledky experimentu poukazujú na skutočnost', že vektorové dlaždice majú čas vykreslenia v aplikácii podstatne dlhší ako rastrové dlaždice, avšak pri väčších mierkach majú kratší čas prenosu údajov, ked’že údaje zo servera prichádzajú ku klientovi v efektívnejšej forme. Vykresl'ovanie rastrových dlaždíc trvá výrazne kratšie, pretože sa vykresl'uje kompaktne ako obrázok bez potreby spracovania dát. Spracovanie dát, príprava kartografickej symboliky a náročnejšie vykresl'ovanie je výrazným záporným elementom v používaní vektorových dlaždíc.

\section{Čas potrebný na vykreslenie geometrie}

Z obr. 4 môžeme pozorovat', že vykresl'ovanie vektorových dát vo vektorových dlaždiciach na strane klienta s prípravou kartografickej symboliky je časovo náročnejší proces ako vykreslenie rastrových dlaždíc. Pri nižších hodnotách priblíženia, kde sa zobrazovalo väčšie územie, mali vektorové dlaždice niekol'konásobne väčšie časy ako pri väčších hodnotách priblíženia; súvisí to s objemom dát bližšie popísaným d’alej. Ďalšími faktormi sú použitá grafická reprezentácia dát a súvisiace operácie - detekcia konfliktov pri generovaní popisov a umiestnenie popisov pozdĺž línie. Kartografická symbolika bola pri vrstvách názvov miest a obcí, ciest a využitia krajiny zvolená na základe hodnôt atribútov vrstiev. Popisy k jednotlivým vrstvám sa vykresl'ujú ako jednoduchý text popisujúci názvy objektov s bielym okolím, tzv. halo efekt, a popisy vodných tokov boli umiestnené pozdliž línií. 


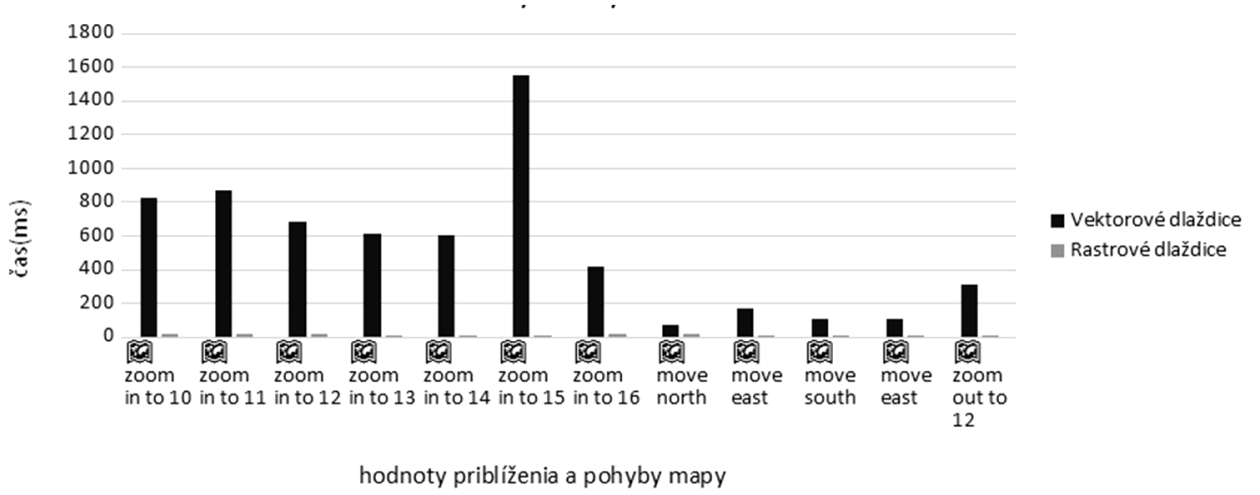

Obr. 4. Porovnanie časov vykreslenia geometrie pri jednotlivých pohyboch mapy (priblíženia, pohyby a oddialenie)

\section{Porovnanie vel'kosti dát vo vektorovej dlaždici a WMTS}

Neupravené vektorové dlaždice posielané zo servera GeoServer nemajú mieru generalizácie na úrovni, ktorá by zodpovedala rozlíšeniu mapy, kde sa dlaždica použije. Preto nie je zabezpečené dostatočné zmenšenie vel'kosti prenášaných a vykresl'ovaných dát. Pri tvorbe vektorových dlaždíc v nižších mierkových úrovniach je vhodné generalizovat' dáta vypustením malých objektov, ktoré sú pod rozlišovaciu úroveň, a zjednodušovat' priebeh línií pri riečnych a cestných siet’ach alebo hraniciach polygónov. Pri zist’ovaní úrovne generalizácie našich dát sme vytvorili jednoduchý parser s využitím knižníc pbf a vector-tile na zobrazenie obsahu vektorovej dlaždice. Pre demonštráciu sme zistili úroveň generalizácie polygónu ohraničujúceho naše záujmové územie. Pôvodný polygón bez generalizácie obsahuje 3873 vertexov. Pri iniciálnom pohl'ade mapy polygón obsahuje 2593 vertexov. Pri oddialení mapového pohl'adu na úroveň priblíženia 1 , kde sa celý rozsah územia v systéme EPSG: 3857 zobrazí na dlaždice v rozsahu $512 \times 512$ px, obsahoval polygón 63 vertexov. Zobrazená vel'kost' polygónu záujmového územia pri tejto úrovni priblíženia zaberá plochu $5 \times 4$ px, z čoho je zrejmé, že na znázornenie tvaru v takomto detaile by postačil zlomok $(5-10)$ vertexov. Pri úrovni priblíženia 2 zo servera ku klientovi dorazilo vo vektorovej dlaždici už 234 vertexov polygónu, čo potvrdzuje vel'mi nízku mieru generalizácie pri tvorbe dlaždíc na mapovom serveri. Táto skutočnost' znižovala mieru pozitívneho efektu pri použití vektorových dlaždíc. Samotná vel'kost' prenášaných dát bola preto prevažne väčšia pri vektorových dlaždiciach ako pri obrazových dlaždiciach. Záležalo však na rozsahu územia a počte zobrazovaných objektov. Vo vel'kých mierkach boli výhodnejšie vektorové dlaždice, pretože bolo zobrazovaných menej prvkov s menej komplexnými tvarmi. Tieto prvky získané ako vektory mali vel'kost' výrazne nižšiu ako v prípade, že sa tieto objekty získavali vo forme rastra. Napríklad v dlaždici so súradnicami v dlaždicovej schéme $[17950,11368,16]$ je zobrazený polygón využitia krajiny, ktorý vo vektorových dlaždiciach obsahuje 4 vertexy a má spolu so všetkými dátami vektorovej dlaždice vel'kost' $1,7 \mathrm{kB}$. V rastrovej dlaždici formátu PNG8 má vel'kost' $8,1 \mathrm{kB}$ a teda takmer 5-krát väčšiu vel'kost' ako dáta vo forme vektora. Z obr. 5 môžeme zistit', že pri úrovni priblíženia 10 prišli vektorové dlaždice s vel'kost'ou $1240 \mathrm{kB}$ a rastrové dlaždice s vel'kost'ou $255 \mathrm{kB}$. Na obr. 5 vidí- 
me v úrovni priblíženia 13 a 14 mierny nárast vel'kosti dát pri vektorových dlaždiciach, ktorý je spôsobený zobrazením miestnych komunikácií, resp. prístupových ciest. Pri ideálnej miere generalizácie by jednotlivé časti v grafe, reprezentujúce vektorové dlaždice, vytvárali približne lineárny priebeh. Ked’že podl'a našich uvedených zistení je úroveň generalizácie nepostačujúca a posiela sa nadbytočný počet vertexov prvkov, priebeh lineárny nie je. Finálny pohyb mapy, oddialenie na hodnotu priblíženia 12, vyžaduje zo servera len čast' dát v porovnaní so zobrazením pri tom istom priblížení pri predchádzajúcich krokoch, pretože znázornený územný rozsah sa čiastočne prekrýva a využili sa už získané dlaždice.

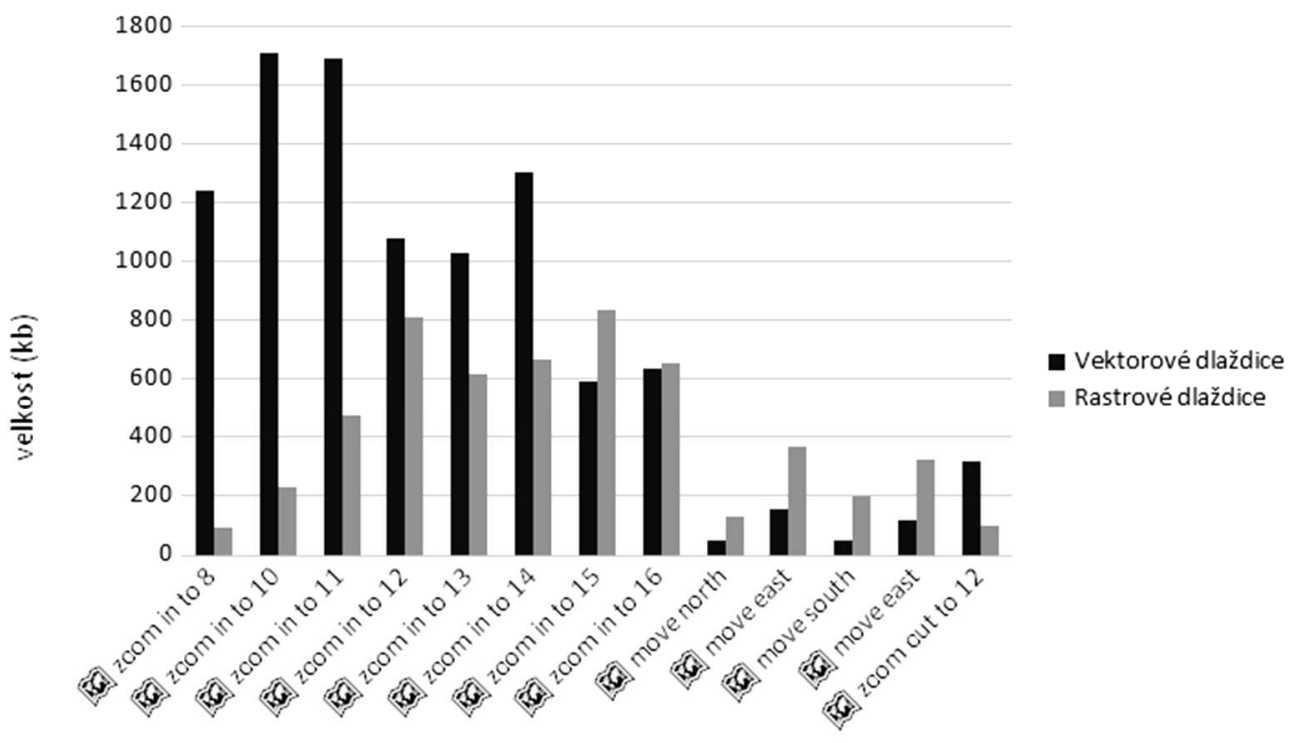

hodnoty približenia a pohyby mapy

Obr. 5. Vel'kost' objektov vo vektorových a rastrových dlaždiciach

Čas prenosu vrstiev zo servera ku klientovi

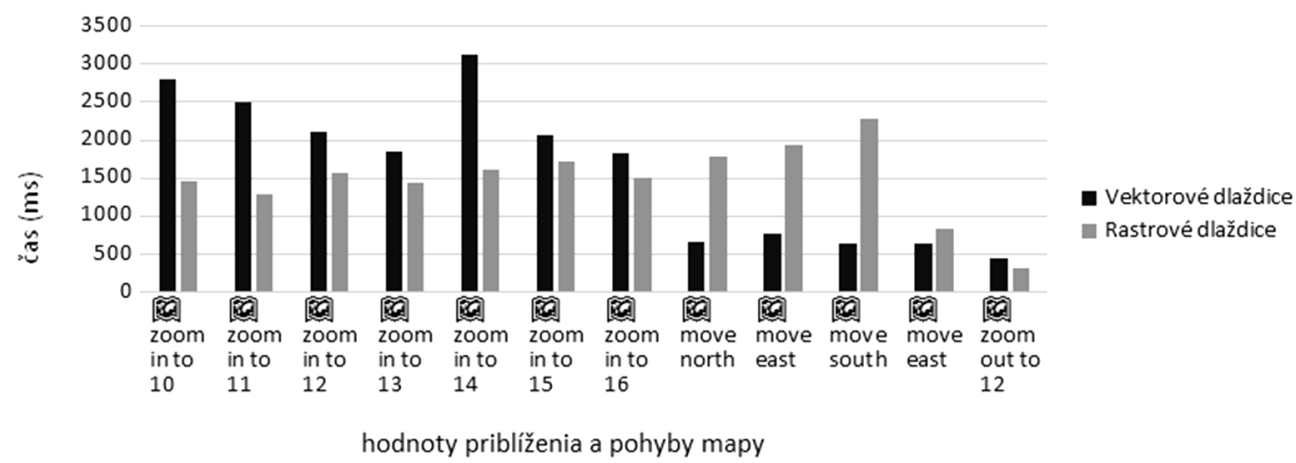

Obr. 6. Porovnanie časov medzi prvou a poslednou dopytovanou dlaždicou 
Na obr. 6 vidíme časy, ktoré zobrazujú čas medzi prvým a posledným dopytom na dlaždice. Tieto časy boli ovplyvnené vel'kost'ou dát a priebehom vykresl'ovania. $\mathrm{V}$ úrovni priblíženia 15 môžeme pozorovat' mierny nárast. Je spôsobený odosielaním vrstvy budov s vel'kým počtom objektov.

\section{ZÁVER}

Na základe dosiahnutých výsledkov môžeme tvrdit', že zobrazovanie dát vo forme vektorových dlaždíc má svoje nevýhody, ktoré treba brat' do úvahy. Nevýhody sa prejavia výraznejšie pri nedostatočnej optimalizácii pri tvorbe vektorových dlaždíc, ako sme to prezentovali vo výsledkoch. Špecifikácia spoločnosti Mapbox, popisujúca architektúru vektorových dlaždíc, zámerne neuvádza najvhodnejší spôsob generalizácie údajov, sú spomenuté len jej riziká. Pri zobrazení v menších mierkach je však výhodnejšie použit' vektorové dlaždice iba v prípade, že dáta sú dostatočne generalizované, čím sa zabezpečí neprenášanie nadbytočných a nevyužitel'ných údajov. Pri zobrazovaní vo vel'kých mierkach je tento problém menej významný. Vel'kou výhodou vektorových dlaždíc, ktorú treba vnímat' v kontexte vykonaného experimentu, je, že pre vyššie úrovne priblíženia klient nepotrebuje získat' d’alšie dáta a vykreslí mapový obsah zo získaných dát (so zachovaním kvality vykreslenia). Naopak pri rastrových dlaždiciach pritom potrebuje získat' mnoho d’alších dát - v každej d’alšej úrovni až 4-krát viac dlaždíc, ktoré často pre diskovú kapacitu servera ani nemôžu byt' predgenerované.

\section{LITERATÚRA}

ADAMEC, L. (2016). Vektorové dlaždice ve webové kartografii. Diplomová práca, Př́rodovědecká fakulta, Masarykova Univerzita, Brno

ANTONIOU, V., MORLEY, J., HAKLAY, M. (2009). Tiled vectors: a method for vector transmission over the Web. In Proceedings of 9th International Symposium, W2GIS 2009, Maynooth, Ireland, December 7-8, 2009. Berlin, Heidelberg (Springer), pp. 56-71 DOI: https://doi.org/10.1007/978-3-642-10601-9_5.

FISCHER, E. (2017). Tippecanoe, [Online]. Available: https://github.com/mapbox/ tippecanoe [accessed 29 May 2019].

GAFFURI, J. (2012). Toward web mapping with vector data. In Proceedings of 7th International Conference, GIScience 2012, Columbus, OH, USA, September 18-21, 2012, Berlin, Heidelberg (Springer), pp. 87-101. DOI: https://doi.org/10.1007/978-3-64233024-7 7.

GOOGLE Inc. (2010). Under the hood of Google Maps 5.0 for Android, [Online]. Available: http://googlemobile.blogspot.com/2010/12/under-hood-of-google-maps-50-for.html [accessed 08 May2019].

HENNEBERGER, S. (2015). GeoServer - Rendering Binary Vector Tiles, [Online]. Available: https://www.salzburgresearch.at/blog/geoserver-rendering-binary-vector-tiles/ [accessed 29 April 2019].

JANEČKA, K., BOBÍKOVÁ, D. (2018). Registering the underground objects in the 3D cadastre: a case study of wine cellar located in the vineyard area Tokaj. Acta Montanistica Slovaca, 23, 260-270.

LI, Ch., LU, H., XIANG, Y., LIU, Z., YANG, W., LIU, R. (2018). Bringing geospatial data closer to mobile users: a caching approach based on vector tiles for wireless multichip scenarios. Mobile Information Systems, Article ID 5186495. 18 p. DOI: $10.1155 / 2018 / 5186495$.

LI, L., HU, W., ZHU, H. LI, Y., ZHANG, H. (2017). Tiled vector data model for the geographical features of symbolized maps. PLoS ONE 12(5): e0176387. DOI:10.1371/ journal.pone.0176387. 
MAPBOX (2016). Vector tile specification, [Online]. Available: https://docs.mapbox.com/ vector-tiles/specification/ [accessed 29 April 2019].

MAPBOX. (2017). Vector tile specification, [Online]. Available: https://github.com/ mapbox/vector-tile-spec/tree/master/2.1 [accessed 29 April 2018].

MIGURSKI, M. (2019). TileStache API, [Online]. Available: http://tilestache.org/doc/ [accessed 29 April 2019].

OGC (2018a). Vector tiles pilot, [Online]. Available: http://www.opengeospatial.org/ projects/initiatives/vt-pilot-2018 [accessed 08 May 2019].

OGC (2018b). OGC Vector tiles pilot: summary engineering report, [Online]. Available: https://docs.opengeospatial.org/per/18-086r1.html\#_conclusion [accessed 08 May 2019].

OPENSTREETMAP WIKI CONTRIBUTORS. (2019). Zoom levels, [Online]. Available: https://wiki.openstreetmap.org/wiki/Zoom_levels [accessed 29 April 2019].

PYWELL, H. R., NIEDZWIADEK, H. A. (1980). The wetlands analytical mapping system: WAMS. In Proceedings of the Analytical Plotter Symposium and Workshop, Reston, Virginia, April 1980. Falls Church (American Society of Photogrammetry), pp. 261-269.

REED, C. N. (2017) DeltaMap/GenaMap Tiled Topological and Coverage (Raster) Data Structure, [Online]. Available: https://sites.google.com/site/reedsgishistory/Home/ deltamap-genamap-tiled-topological-data-structure [accessed 27 September 2018].

ROELOFS, G. (2006). Chapter 8. PNG Basics, [Online]. Available: http://www.libpng.org/ pub/png/book/chapter08.html\#png.ch08.div.5.1 [accessed 28 May 2019].

THOMPSON, B. (2016). Mapbox vector tile specification 2.0, [Online]. Available: https://2016.foss4g-na.org/sites/default/files/slides/VectorTileSpec-2.0.pdf [accessed 08 April 2018].

Jozef Fábry, Richard Fec is $k$ a $n$ in

\section{PUBLISHING GEODATA IN THE FORM OF VECTOR TILES AND COMPARING PERFORMANCE WITH RASTER TILES}

The differences between vector and raster tile technologies, especially when they are used in client application, causes significant differences in user output preparation. In this paper we pointed out the fact, that using vector tiles, specifically the open specification from Mapbox in MVT, despite the undeniable advantages, is not advantageous to use in any case. We evaluated the rendering of geometry quantitatively and the time of data transfer from the server to the client. Fig. 4 shows that the times of vector tile rendering is greater than those of raster tiles. This is due to complex object rendering operations. In comparison with the transferred data size (Fig. 5), it has been confirmed in vector tiles that the data size saves at a larger zoom level. In addition, on a large scale it is not necessary to retrieve data from the server, but the map content is rendered from the complete data obtained from the lower zoom levels. At lower zoom levels, a larger volume of data comes to the client due to the size of the area and the details of elements. The data analysis confirmed that the low level of generalization of the shape of the objects contributed significantly to this. Overall, we can evaluate the results so that when displayed on smaller scales, it is preferable to use vector tiles only if the data is sufficiently generalized, which was not met in the case of the experiment performed. 
